\title{
Efektifitas Pijat Bayi terhadap Peningkatan Berat Badan Bayi di Ruang Perinatologi RSU Inanta Kota Padangsidimpuan
}

\author{
Sri Sartika Sari Dewi ${ }^{1}$, Delfi Ramadhini², Yulinda Aswan ${ }^{3}$ \\ 1,2,3 Universitas Aufa Royhan Padangsidimpuan Indonesia \\ Email: srisartikasaridewi@gmail.com
}

Submitted : 21/10/2020

Accepted: 06/01/2021

Published: 06/03/2021

\begin{abstract}
The growth and development period of a baby is a golden period as well as a critical period for a person's development, namely the age of 0-12 months. It is said that the critical period is because at this time babies are very sensitive to the environment and need good nutrition and stimulation for their growth and development. Stimulation or stimulation can be done through massage which is useful to stimulate all the work of the sensory and motor systems. Massage in babies will also stimulate the vagus nerve to increase intestinal peristalsis, so that gastric emptying is faster and will stimulate the baby's appetite to eat more heartily in sufficient quantities. On the other hand, baby massage can also improve blood circulation and increase cell metabolism, so that the baby's weight will increase. The purpose of this study was to identify the effectiveness of infant massage in increasing infant weight. This research uses qualitative research with a quasi-experimental design. The number of samples in this study were 22 people in the intervention group. Sampling was done using accidental sampling. This research was conducted in the Perinatology Room of Inanta Hospital, Padangsidimpuan City. Data analysis using t-dependent test. The results of the statistical test showed that the value of $p=0.000$, it can be concluded that there is a significant difference in the baby's body weight before and after the massage in the intervention group. From the results of this study, it is known that baby massage is very effective in increasing the baby's weight. so that baby massage can also be used as an intervention in midwifery care for babies so that the baby's growth and development can be achieved optimally.
\end{abstract}

Keywords: baby massage, baby weight

\begin{abstract}
Abstrak
Masa tumbuh kembang bayi merupakan masa keemasan (golden period) sekaligus masa kritis perkembangan seseorang yaitu usia 0-12 bulan. Dikatakan masa kritis karena pada masa ini bayi sangat peka terhadap lingkungan dan membutuhkan asupan gizi serta stimulasi yang baik untuk pertumbuhan dan perkembangannya. Stimulasi atau rangsangan bisa dilakukan melalui pemijatan yang berguna untuk merangsang semua kerja sistem sensorik dan motorik. Pemijatan pada bayi juga akan merangsang nervus vagus meningkatkan peristaltik usus, sehingga pengosongan lambung lebih cepat dan akan merangsang nafsu makan bayi untuk makan lebih lahap dalam jumlah yang cukup. Disisi lain pijat bayi juga dapat memperlancar peredaran darah dan meningkatkan metabolisme sel, sehingga berat badan bayi akan meningkat. Tujuan penelitian ini adalah untuk mengidentifikasi efektifitas pijat bayi terhadap peningkatan berat badan bayi. Penelitian ini menggunakan jenis penelitian kualitatif dengan desain quasi eksperimen. Jumlah sampel dalam penelitian ini adalah 22 orang pada kelompok intervensi. Pengambilan sampel dilakukan dengan menggunakan accidental sampling. Penelitian ini dilakukan di Ruang Perinatologi RSU Inanta Padangsidimpuan. Analisa data menggunakan uji $t$-dependent. Hasil uji statistik didapatkan nilai $\mathrm{p}=0.000$, maka dapat disimpulkan bahwa ada perbedaan signifikan berat badan bayi sebelum dan setelah dipijat pada kelompok intervensi. Dari hasil penelitian ini, diketahui bahwa pijat bayi sangat efektif dalam meningkatkan berat badan bayi. sehingga pijat bayi dapat digunakan juga sebagai intervensi dalam asuhan kebidanan pada bayi agar tumbuh kembang bayi bisa tercapai dengan optimal.
\end{abstract}

Kata kunci: berat badan bayi, pijat bayi 


\section{PENDAHULUAN}

Pijat bayi adalah terapi sentuh tertua yang dikenal manusia yang paling populer. Pijat bayi telah lama dilakukan hamper di seluruh dunia, mempertahankan perasaan aman pada bayi. Laporan tertua tentang seni pijat untuk pengobatan tercatat di Papyrus Ebers, yaitu catatan kedokteran zaman mesir kuno, Ayur- Veda buku kedokteran tertua di India (sekitar 1800 sebelum Masehi) yang menuliskan tentang pijat, diet dan olahraga sebagai cara penyembuhan utama masa itu. Sekitar 5000 tahun yang lalu para dokter di cina dari Dinasti Tang juga meyakini bahwa pijat adalah salah satu 4 teknik pengobatan penting (Roesli, 2008).

Pemerintah telah memberikan perhatian terhadap bayi melalui peran bidan sendiri yang tertuang dalam Keputusan Menteri Kesehatan Republik Indonesia Nomor 369/MENKES/SK/III/2007.

Tentang

Standar Profesi Bidan yang menyebutkan bahwa bidan mempunyai kewenangan untuk melaksanakan pemantauan dan menstimulasi tumbuh kembang bayi dan anak. Salah satu bentuk stimulasi tumbuh kembang yang selama ini dilakukan adalah pijat bayi (Kepmenkes RI, 2007). Pemijatan pada bayi juga akan merangsang nervus vagus. Saraf ini akan meningkatkan peristaltik usus, sehingga pengosongan lambung lebih cepat dengan demikian akan merangsang nafsu makan bayi untuk makan lebih lahap dalam jumlah yang cukup. Selain itu nervus vagus juga dapat memacu produksi enzim pencernaan makanan maksimal. Disisi lain pijat bayi juga dapat memperlancar peredaran darah dan meningkatkan metabolisme sel, sehingga berat badan bayi akan meningkat (Health and Bainbridge,2009).

Pelaksanaan pijat bayi di Indonesia khususnya di masyarakat desa masih dipegang oleh dukun bayi. Selama ini pemijatan tidak hanya dilakukan bila bayi sehat, tetapi juga pada bayi sakit atau rewel dan sudah menjadi rutinitas perawatan bayi setelah lahir. Menurut Sari (2004, dalam Prasetyono, 2009). Pijat bayi sebagai salah satu bentuk bahasa sentuhan ternyata memiliki efek yang positif untuk pertumbuhan dan perkembangan bayi. Seiring dengan perkembangan ilmu pengetahuan dan teknologi, para pakar telah membuktikan bahwa terapi sentuh dan pijat menghasilkan perubahan psikologi yang menguntungkan berupa peningkatan pertumbuhan, peningkatan daya tahan tubuh, dan kecerdasan emosi yang lebih baik (Roesli, 2008 dalam Prasetyono, 2009).

Ilmu kesehatan modern telah membuktikan secara ilmiah bahwa terapi sentuh dan pijat pada bayi mempunyai banyak manfaat terutama bila dilakukan sendiri oleh orang tua bayi. Penelitian tentang pengaruh pijat bayi terhadap kenaikan berat badan bayi memperoleh hasil bahwa pada kelompok kontrol kenaikan berat badan sebesar 6,16\%, sedangkan pada kelompok yang dipijat 9,44\% (Kurnia, 2009, dalam Prasetyono,2009).

Dari hasil survei pendahuluan yang dilakukan oleh peneliti di ruang perinatologi RSU Inanta Kota Padangsidimpuan pada tanggal 29 Juli 2019 peneliti mendapatkan informasi dari kepala ruangan perinatologi bahwa pijat bayi tidak pernah dilakukan pada bayi baru lahir. Perawatan yang dilakukan hanya memandikan dan membersihkan tali pusat. Maka dari itu, peneliti tertarik untuk melakukan penelitian tentang " Efektifitas Pijat Bayi Terhadap Peningkatan Berat Badan bBayi Di Ruang Perinatologi RSU Inanta Kota Padangsidimpuan".

\section{METODE PENELITIAN}

Penelitian ini menggunakan jenis penelitian kualitatif dengan desain quasi 
eksperimen, untuk mengetahui efektifitas pijat bayi terhadap berat badanbayi.

Jumlah sampel dalam penelitian ini adalah 22 orang pada kelompok intervensi, dengan metode pengambilan sampel menggunakan accidental sampling. Penelitian ini dilakukan di Ruang Perinatologi RSU Inanta Padangsidimpuan. Analisa data univariat dan bivariat dengan menggunakan bantuan program SPSS. Analisa data bivariate menggunakan ujitdependent.

Instrumen dalam penelitian ini menggunakan lembar observasi, yang berisi tentang data demografi, yaitu usia bayi,berat badan bayi waktu lahir, anak ke dalam keluarga. Selanjutnya untuk mengobservasi peningkatan berat badan bayi sebelum dansesudah dilakukan pemijatan yaitu dengan menggunakan timbangan berat badan BabyScale Sella yang sudah terstandarisasi dan sudah digunakanuntuk menimbang berat badan bayi secaraberulangyang sebelumnya sudah ditera (skala 0) untuk mendapatkan hasil yangsama.

Pijat bayi dilakukan 1 kali sehari dalam 15 menit selama 10 hari dan peningkatan berat badan bayi di observasi selama 10 hari. Dalam memberikan

pemijatanpenelitibekerjasamadengan

anggota peneliti. Terlebih dahulu peneliti mengajarkan tata cara pijat bayi kepada anggota peneliti. Setelah 10 hari dilakukanpenimbangan kembali terhadapkelompok intervensi untuk mengetahui beratbadan bayi.

\section{HASIL DAN PEMBAHASAN}

Berdasarkan karakteristik data demografi bayi di ruang perinatologi seperti yang terlihat pada tabel 1 berikut:

Tabel 1. Distribusi Responden Berdasarkan Karakteristik Data
DemografiBayi Di Ruang Perinatologi RSU Inanta $(\mathbf{n}=22)$

\begin{tabular}{clcc}
\hline No & Karakteristik & Responden & \\
\hline & & Mean & SD \\
\hline 1 & $\begin{array}{l}\text { Berat badan } \\
\text { lahir }\end{array}$ & $1745 \mathrm{gr}$ & 283.1 \\
\hline 2 & Anak ke & 2 & 1.12 \\
\hline 3 & Usia & 2 hari & 1.4 \\
\hline
\end{tabular}

Berdasarkan tabel 1 diperoleh bahwa rata- rata berat badan lahir responden pada kelompok intervensi adalah 1745 gr dengan standar deviasi 283.1. Berdasarkan urutan anak dalam keluarga rata-rata responden adalah anak ke 2 dengan standar deviasi1.12. Berdasarkan usia rata-rata usia responden adalah hari dengan standar deviasi 1.4.

Tabel 2. Distribusi Berat Badan Bayi Sebelum dan Sesudah Dilakukan Pemijatan di Ruang Perinatologi RSU Inanta $(\mathbf{n}=22)$

\begin{tabular}{llcc}
\hline No & Variabel & \multicolumn{2}{c}{ Kelompok Intervensi } \\
\cline { 3 - 4 } & & Mean & SD \\
\hline 1 & $\begin{array}{l}\text { Berat badan } \\
\text { responden } \\
\text { sebelum } \\
\text { dipijat }\end{array}$ & $\begin{array}{c}1768 \\
\text { gr }\end{array}$ & 256.12 \\
\hline 2 & $\begin{array}{l}\text { Berat badan } \\
\text { responden } \\
\text { setelah } \\
\text { dipijat }\end{array}$ & gr & \\
\hline
\end{tabular}

Berdasarkan tabel 2. rata-rata berat badan bayi sebelum dipijat pada kelompok intervensi adalah 1768 gr dengan standar deviasi 256.12 dan rata-rata berat badan bayi setelah dipijat adalah 2128 gr dengan standar deviasi 251.55.

Analisa Bivariat

Analisa ini digunakan untuk menguji efektifitas pijat bayi dalam meningkatkan berat badan bayi. Untuk uji t-dependent dapat dilihat pada tabel dibawah ini. 
Tabel 3. Pengaruh Pijat Bayi terhadap Peningkatan Berat Badan Bayi Sebelum dan Sesudah Dilakukan Pemijatan di RuangPerinatologi RSU Inanta (n=22)

\begin{tabular}{lll}
\hline No & Variabel & Mean \\
\hline 1 & $\begin{array}{l}\text { Berat badan responden } \\
\text { sebelum dipijat }\end{array}$ & 1768 gr \\
\hline 2 & $\begin{array}{l}\text { Berat badan responden } \\
\text { Setelah dipijat }\end{array}$ \\
\hline & Berdasarkan tabel 3. diperoleh rata- \\
rata berat badan bayi sebelum dilakukan \\
pemijatan adalah 1768 gr dengan standar \\
deviasi 256.12 dan rata-rata berat badan \\
bayi setelah dipijat adalah 2128 gr dengan \\
standar deviasi 251.55. Terlihat perbedaan \\
mean sebelum dipijat dan setelah dipijat \\
adalah 360 gr dengan standar deviasi \\
112.328. Hasil uji statistik didapatkan nilai \\
p= 0.000, maka dapat disimpulkan bahwa \\
ada perbedaan signifikan berat badan bayi \\
sebelum dan setelah dipijat pada kelompok \\
intervensi.
\end{tabular}

\section{Interpretasi dan diskusi hasil}

Hasil penelitian data demografi responden didapat rata-rata berat badan responden adalah 1745 gr dengan standar deviasi 283.1, rata-rata anak ke 2 dengan standar deviasi 1.12 dan rata- rata usia responden 2 hari dengan standardengan standar deviasi 251.55, Selanjutnya hasil uji statistik t-dependent diperoleh kesimpulan bahwa ada perbedaan yang signifikan pada peningkatan berat badan bayi sebelum dan sesudah dilakukan pemijatan dengan taraf signifikan $0.000(\mathrm{P}<0.05)$.

Oleh karena itu, penelitian ini sesuai dengan pernyataan bahwa ilmu kesehatan modern telah membuktikan secara ilmiah bahwa terapi sentuh dan pijat pada bayi mempunyai banyak manfaat terutama bila dilakukan sendiri oleh orang tua bayi (Dasuki, 2003, dalamPrasetyono,2009).

Demikian juga, penelitian di Australia yang di ungkapkan oleh Lana Kristiane F.Flores membuktikan bahwa bayi yang depresi dan ketenangan, membuat bayi tidur lelap, mengurangi rasa sakit,

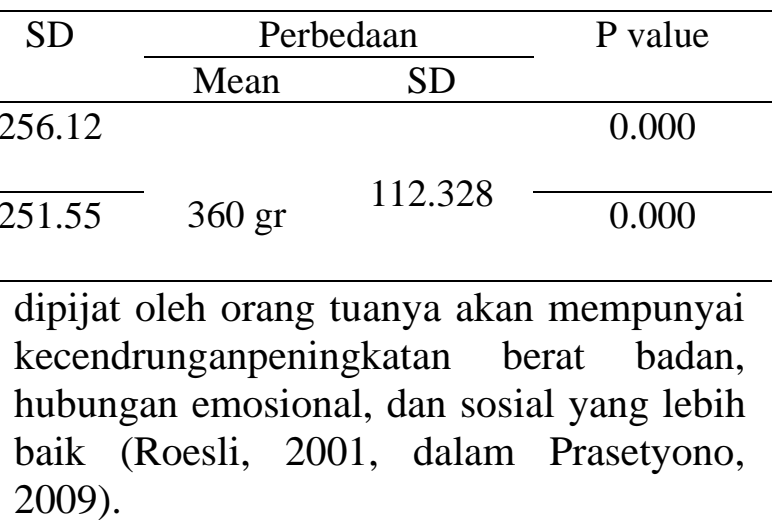

Menurut Roesli (2001) Pijat bayi adalah seni perawatan kesehatan dan pengobatan yang dikenal sejak awal manusia diciptakan di dunia serta telah dipraktikkan sejak berabadabadtahunsilam secaraturun temurun oleh dukun bayi.

Roesli (2001) mengatakan, para pakar dewasa ini telah dapat membuktikan secara ilmiah bahwa terapi sentuh khususnya pijat bayi, ternyata bermanfaat. Pijat bayi terbukti dapat menhasilkan perubahan fisiologis yang menguntungkan, yang dapat diukur secara ilmiah. Pengukuran secara ilmiah ini antara lain dengan cara mengukur kadar cortisol ludah, kadar cortisol plasma secara radioimmunoassay, kadar hormon stres atau catecholamine air seni, dan pemeriksaan EEG (electro encephalogram). Dampak biokimia yang positif yang terjadi pada bayi prematur yang dipijat adalah penurunan kadar hormon stres dan penigkatan kadar zat daya tahan tubuh terutama IgG, IgA dan IgM. Sedangkat dampak klinis yang positif adalah peningkatan jumlah sel daya racun dari sistem imunitas, mengubah gelombang otak secara positif, memperbaiki sirkulasi darah dan pernafasan, merangsang fungsi pencernaan serta pembuangan, meningkatkan berat badan, mengurangi 
mengurangi kembung dan sakit perut, meningkatkan hubungan orang tua dan bayi, meningkatkan volume air susu ibu.

Adapun manfaat pijat bayi secara umum adalahkekuatandan kelenturanfikiran, tubuh dan emosi dapat ditingkatkan, tidur dapatberkualitas, restrukturisasi tulang, otot dan organ yang dapat dibantu, cedera lama dan baru dapat disembuhkan, konsentrasi dan ingatan dapat ditingkatkan (Gichara,2006).

Selain manfaat diatas, terdapat manfaat lain seperti adalah meningkatkan berat badan, meningkatkan pertumbuhan, meningkatkan daya tahan tubuh, meningkatkan konsentrasi bayi dan mebuat bayi tidur lebih lelap, membina ikatan kasih sayang orang tua dan anak, meningkatkan produksi ASI (Roesli, 2001).

Dari hasil penelitian initerlihat perbedaan peningkatan berat badan bayiyang dipijat dan yang tidak dipijat, yang mana diperoleh hasilbahwaterjadi kenaikan berat badan bayi sebesar $8,52 \%$.

Penelitian ini juga, di dukung dengan penelitian T.Field dan Scafidi (1986 dan 1990, dalam Roesli, 2008, hal 12) yang menunjukkan bahwa pada 20 bayi prematur (berat badan1.280 dan 1.176 gr), yang dipijat selama 3 kali 15 menit selama 10 hari, terjadi kenaikan berat badan 20\% $47 \%$ per hari, lebih dari yang tidakdipijat.

\section{SIMPULAN}

Hasil penelitian,dari karakteristik responden diperoleh rata-rata berat badan lahir responden adalah 1754 gr, rata-rata urutan anak dalam keluarga anak ke 2, dan berusia2 hari dan.Sebelum dilakukan pemijatan rata-rata berat badan bayi adalah 1768 gr dengan standar deviasi256.12. Setelah dilakukan pemijatan diperoleh rata- rata berat badanbayi adalah2128gr dengan standar deviasi 251.55. Nilai rata- rata perbedaan antara sebelum dan setelah dipijat adalah $360 \mathrm{gr}$ dengan standar deviasi112.328. hasil uji statistik diperoleh nilai $\mathrm{P}=0.000$. Maka dapat disimpulkanada perbedaan yang signifikan pada berat badan sebelum dan setelah dilakukan pemijatan.

\section{SARAN}

Hasil penelitian inimenunjukkan bahwa pemijatan memberikanmanfaat untuk meningkatkan berat badan bayidi Ruang Peinatologi RSU Inanta Kota Padangsidimpuan. Oleh karena itu, penting untuk diinformasikan dan diterapkan bahwa pemijatan adalah salah satu intervensi non- farmakologikuntuk meningkatkanberat badan bayi di berbagai tatanan pelayanan kesehatan baik di Rumah Sakit, Klinik, uskesmas maupun dimasyarakat. Diharapkan pada penelitian selanjutnya dapat melanjutkan penelitian yang sejenis,tetapi pemijatan dilakukan pada kelompok yang berbeda yaitu kelompok intervensi dan kelompok kontrol, agar diperoleh hasil yang lebih efektifserta dapat memperbesar jumlah sampel dalam penelitian tersebut.

\section{DAFTAR PUSTAKA}

Chapman, V. (2006). Asuhan Kebidanan Persalinan \& Kelahiran. Jakarta: EGC

Field, T \& Scafidi (1986 \& 1990) dalam Roesli, U. (2008). Pedoman Pijat Bayi Prematur \& Bayi Usia 0-3 Bulan. Jakarta: TrubusAgriwidya.

Gichara, J. (2006). Manfaat Pijat Untuk Ibu Hamil, Pasca Melahirkan \& Bayi. Jakarta: Papas Sinar Sinanti.

Johnson, R \& Taylor, W. (2005). Buku Ajar Praktik Kebidanan. Jakarta: EGC

Kartika. (2008). Sehat Setelah Melahirkan.Sidowayah-Klaten:

Kawan Kita 
Kurnia,

S.

Nova.

(2009).MenghindariGangguan Saat Melahirkan \& Panduan Lengkap Mengurut Bayi. Yogyakarta : Panji Pustaka

Maryunani, A. (2009). Asuhan Kegawatdaruratan Dan Penyulit Pada Neonatus, Jakarta: Trans Info Media.

Prasetyono, D.S. (2009). Teknik-Teknik Tepat Memijat Bayi Sendiri. Yogjakarta: Diva Press.

Roesli, U. (2008). Pedoman Pijat Bayi Prematur \& Bayi Usia 0-3 Bulan. Jakarta: Trubus Agriwidya. 